\title{
Stratigraphy of the Lower Paleozoic Goldenville and Halifax groups in southwestern Nova Scotia
}

\author{
Chris E. White \\ Nova Scotia Department of Natural Resources, P.O. Box 698, Halifax, Nova Scotia B3J 2T9, Canada \\ <whitece@gov.ns.ca>
}

Date received: 11 September 2009 g Date accepted: 03 June 2010

\begin{abstract}
Regional mapping and petrological studies have led to revision of the Cambrian-Ordovician stratigraphy in southwestern Nova Scotia. The Goldenville and Halifax formations have been elevated to groups, and formations have been defined in each group. In the northwestern part of the area, the Goldenville Group is divided into the metasandstonedominated Church Point formation and the overlying metasiltstone-dominated Bloomfield formation. The Church Point formation contains a metasiltstone unit (High Head member) with a distinctive trace-fossil assemblage characteristic of the Early Cambrian, consistent with detrital U-Pb zircon ages. The detrital U-Pb zircon data also suggests that the Goldenville Group below the High Head member is Early Cambrian but allows the Goldenville Group to extend into the Neoproterozoic. Units in the overlying Halifax Group are the slate-rich Acacia Brook formation and overlying metasandstone-dominated Bear River formation.

In the southeastern part of the area, southeast of the Chebogue Point shear zone, the lowestmost unit in the Goldenville Group is a fine-grained metasandstone-slate package termed the Moses Lake formation. It is overlain by a thickly bedded, medium-grained metasandstone-dominated unit termed the Green Harbour formation that is similar in appearance to the Church Point formation. The upper part of the Goldenville Group consists of thinly bedded metasandstone/metasiltstone termed the Government Point formation. No equivalent unit is recognized in the northwestern area. The uppermost part consists of Mn-rich metasiltstone of the Moshers Island formation that is stratigraphically equivalent to the Bloomfield formation, although the latter lacks the characteristic Mn-rich beds. Units in the overlying Halifax Group include the black slate-rich Cunard formation and overlying grey slate-dominated Feltzen formation. The upper part of the Government Point formation farther east has yielded early Middle Cambrian trilobite fossils of Acado-Baltic affinity. The upper parts of the Bear River formation in the northwestern area and Feltzen formation in the southeastern areas locally contains the Early Ordovician graptolite Rhabdinopora flabelliformis, suggesting that the underlying Acacia Brook, Cunard, Bloomfield, and Moshers Island formations are Middle to Late Cambrian, and that a significant unconformity exists between the Halifax Group and the overlying Silurian White Rock Formation. A revised minimum thickness for the combined Goldenville and Halifax groups is $11 \mathrm{~km}$.
\end{abstract}

\section{RÉSUMÉ}

Des travaux de cartographie et des études pétrologiques dans la région ont donné lieu à une révision de la stratigraphie du Cambrien et de l'Ordovicien dans le sud-ouest de la Nouvelle-Écosse. Les Formations de Goldenville et de Halifax ont été désignées comme groupes, tandis que des formations leur ont été attribuées. Dans la partie nordouest de la région, le groupe de Goldenville se répartit entre la Formation de Church Point, composée principalement de métagrès, et la Formation sus-jacente de Bloomfield qui comprend surtout de la métasiltite. La Formation de Church Point contient une unité de métasiltite (membre stratigraphique supérieur), accompagnée d'un assemblage d'ichnofossile distinct, caractéristique du début du Cambrien, et qui correspond à un âge de formation détritique établi par la méthode U-Pb sur zircon. Les données chronologiques des matières détritiques établies par la méthode $\mathrm{U}-\mathrm{Pb}$ sur zircon portent à croire également que le groupe de Goldenville que recouvre le membre stratigraphique supérieur date du début du Cambrien, même si ce groupe se prolonge jusque dans les roches du Néoprotérozoïque. Les unités sus-jacentes du groupe de Halifax comprennent la Formation d'Acacia Brook riche en schiste, ainsi que la Formation de Bear River sus-jacente, principalement composée de métagrès.

Dans la partie sud-est de la région, au sud-est de la zone de cisaillement de Chebogue Point, l'unité la plus profonde du groupe de Goldenville est l'assemblage à grains fins de métagrès et de schiste qui porte le nom de Formation de Moses Lake. Cette formation est recouverte d'une épaisse strate à grains moyens de métagrès dominant qui porte le nom de Formation de Green Harbour, dont l'apparence est similaire à celle de la Formation de Church Point. La partie supérieure du groupe de Goldenville se compose de lits minces de métagrès et de métasiltite désignés comme la Formation de Government Point. Aucune autre unité équivalente n'a été établie dans la région du nord-ouest. La partie supérieure se compose du métagrès riche en manganèse de la Formation de Moshers Island, équivalente au plan stratigraphique à la Formation de Bloomfield, bien que cette dernière formation ne présente pas de lits riches 
en manganèse. Les unités du groupe de Halifax sus-jacent comprennent la Formation de Cunard riche en schiste noir, ainsi que la Formation de Feltzen sus-jacente, qui renferme surtout du schiste gris. La partie supérieure de la Formation de Government Point plus à l'est a produit des trilobites d'une affinité acado-baltique datant du début du Cambrien moyen. Les parties supérieures de la Formation de Bear River dans le secteur nord-ouest et la Formation de Feltzen dans les secteurs sud-est contiennent par endroits le graptolite Rhabdinopora flabelliformis du début de l'Ordovicien, ce qui porte à croire que les Formations sous-jacentes d'Acacia Brook, de Cunard, de Bloomfield et de Moshers Island dateraient du Cambrien moyen au Cambrien tardif et qu'il y aurait une discordance importante entre le group de Halifax et la Formation de White Rock sus-jacente, qui date du Silurien. L'épaisseur minimale révisée des groupes combinés de Goldenville et de Halifax est de 11 kilomètres.

[Traduit par la redaction]

\section{INTRODUCTION}

Southern Nova Scotia, known as the Meguma zone or terrane (Schenk 1971; Williams 1979; Williams and Hatcher 1982), or more recently Meguma (Hibbard et al.2006), is characterized by a thick upper Proterozoic to Lower Ordovician turbiditic succession traditionally referred to as the Meguma Group (Stevenson 1959) and subdivided into the Goldenville and Halifax formations (Fig. 1). Schenk $(1995,1997)$ proposed elevation of the Goldenville and Halifax formations to group status and the Meguma Group to Supergroup status, but these recommendations generally were not adopted (e.g., Keppie 2000). However, detailed 1:10 000-scale bedrock mapping (White et al. 1999, 2001, 2005a, b; Horne et al. 2000, 2009a, b, c, d; White and King 2002; White 2003, 2005, 2006, 2007, 2008a; Horne and Pelley, 2007), combined with stratigraphic, geochemical, geochronologic, and isotopic data (Pratt and Waldron 1991; Waldron 1992; White et al. 2005a; Waldron et al. 2009; White 2010; White and Barr in press), has highlighted the need to produce a new stratigraphic paradigm for Meguma. Past schemes were not well defined, offered insufficient details, or proved to be unusable (e.g., Schenk 1995, 1997). The new mapping (references above) led to the identification of regionally mappable divisions within the traditional Goldenville and Halifax formations, thus meeting the requirement of the stratigraphic code for the establishment of formations (North American Commission on Stratigraphic Nomenclature 2005). The purpose of this paper is to propose stratigraphic terminology for the well-mapped southern part of Meguma by describing the new formations, their contact re-

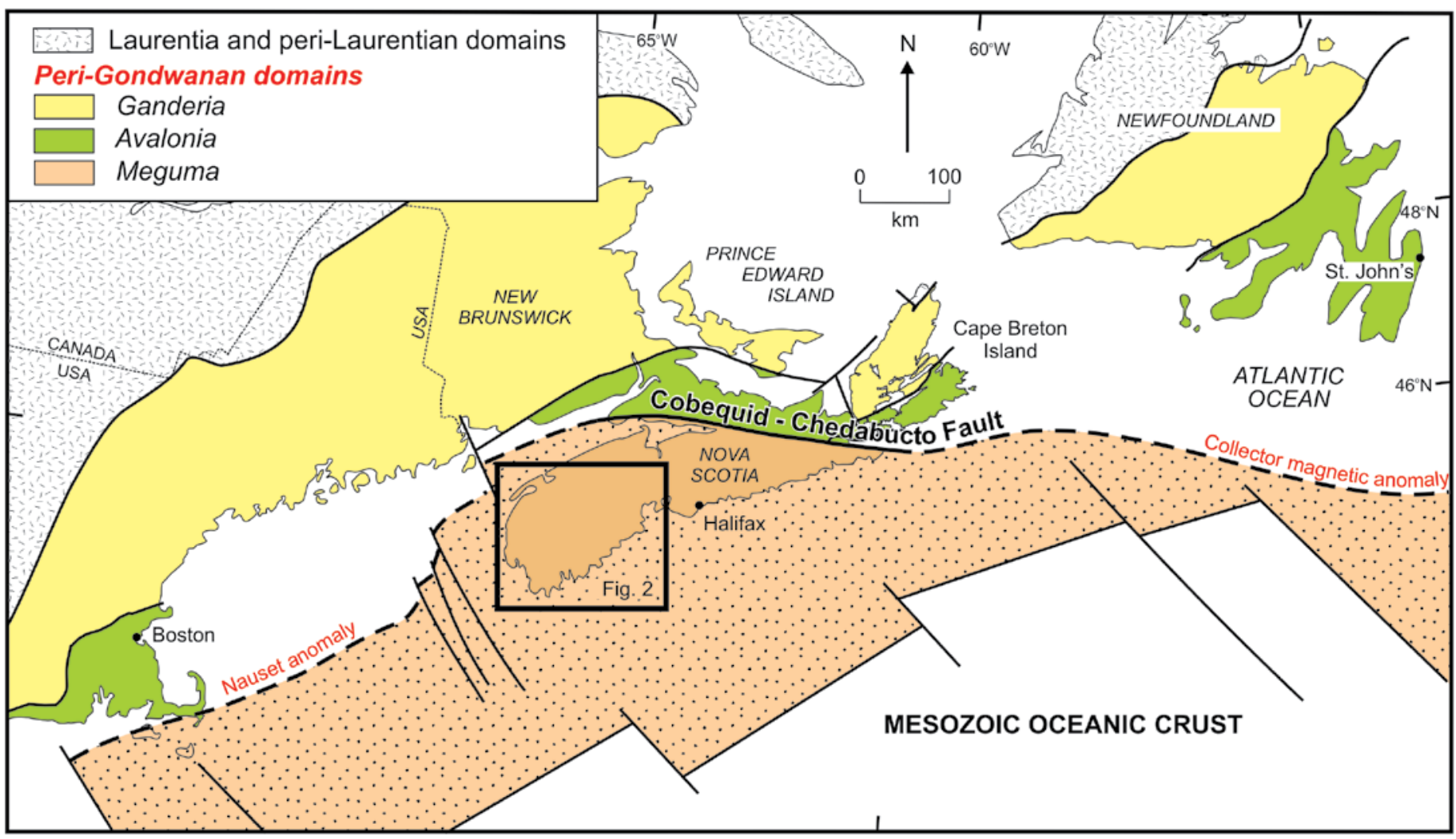

Fig. 1. Location of Meguma and its offshore extension in the context of terranes in the northern Appalachian orogen, modified from Hibbard et al. (2006). Location of the study area indicated by box. 
lations, thicknesses, and where possible type sections or areas. Although it is recognized that more work needs to be done to rigorously formalize these new units following the criteria established by the North American Commission on Stratigraphic Nomenclature (2005), it is also recognized that a start needs to be made. In addition, much of the eastern part of Meguma is not yet covered by recent geological maps and hence the new units proposed here cannot yet be applied to all of Meguma. However, they can be used as a basis for comparison as regional mapping is extended to the eastern part of the terrane.

\section{REGIONAL GEOLOGY}

The turbiditic sequence that characterizes Meguma is divided here into the metasandstone-dominated Goldenville Group and the overlying slate-dominated Halifax Group, both divisible into a number of formations (Fig. 2, 3) as de- scribed in the subsequent section. The youngest detrital zircon from the lowest exposed part of the Goldenville Group yielded an age of $544 \pm 18 \mathrm{Ma}$ (Waldron et al. 2009) and combined with trace-fossil evidence (White et al. 2005a, b; Gingras et al. in press), indicates that the formation is Early Cambrian in age. However, the base is not exposed, so it is possible that the Goldenville Group extends back into the Ediacaran of the upper Proterozoic. A metacarbonate bed near the top of the group yielded Middle Cambrian, Acado-Baltic trilobite fragments (Pratt and Waldron 1991), and graptolites and acritarchs in the upper part of the overlying Halifax Group indicate an Early Ordovician age (Cumming 1985; White et al. 2006; Palacios et al. 2009).

Along the northwestern margin of Meguma, northwest of the Chebogue Point shear zone (Fig. 2), the Halifax Group is disconformably overlain by mainly Silurian, shallow marine sedimentary rocks of the White Rock Formation and equivalent units (Lane 1975, 1981; Bouyx et al. 1997; White in press).

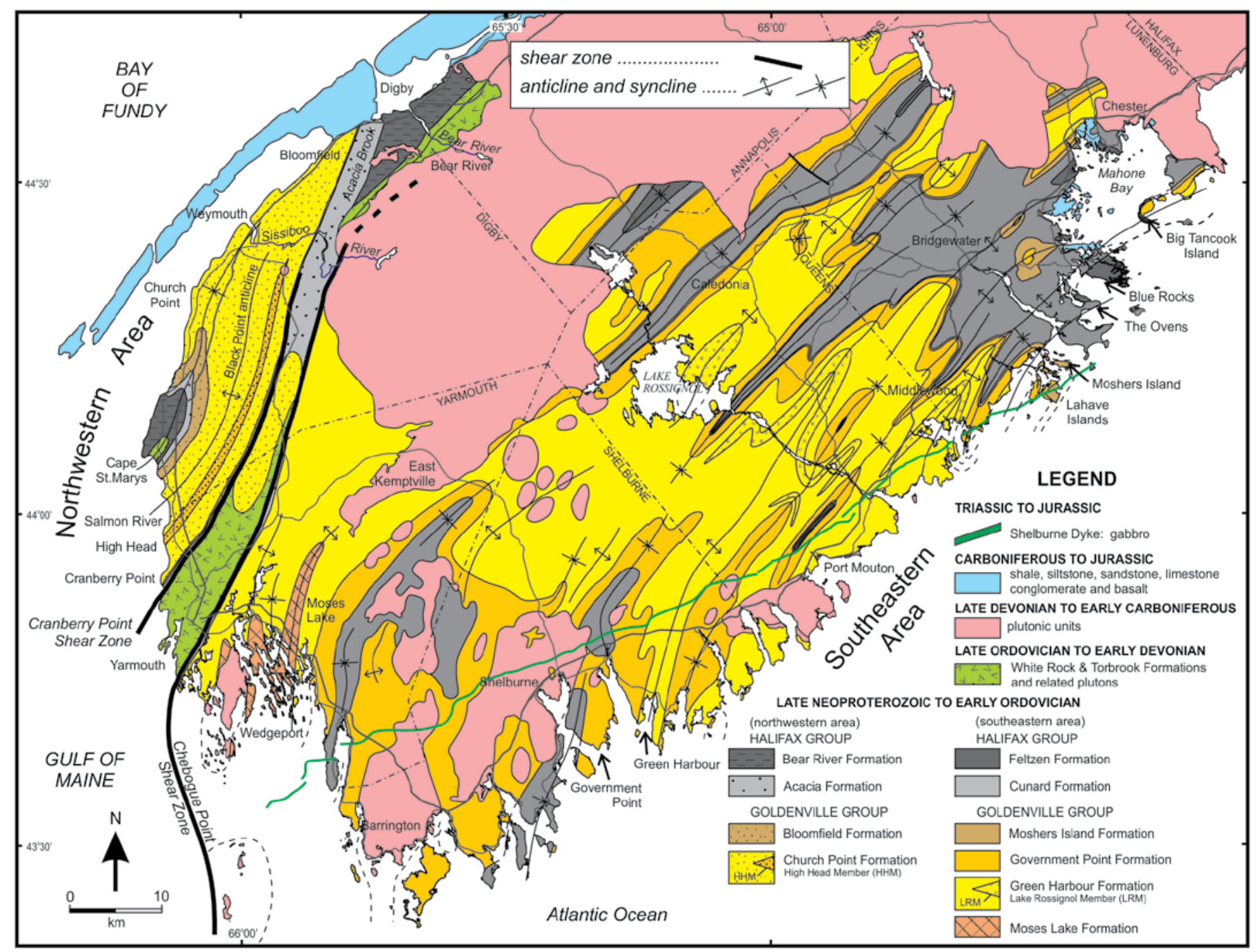

Fig. 2. Simplified geological map of the southwestern part of Nova Scotia compiled from the various sources cited in the text. 


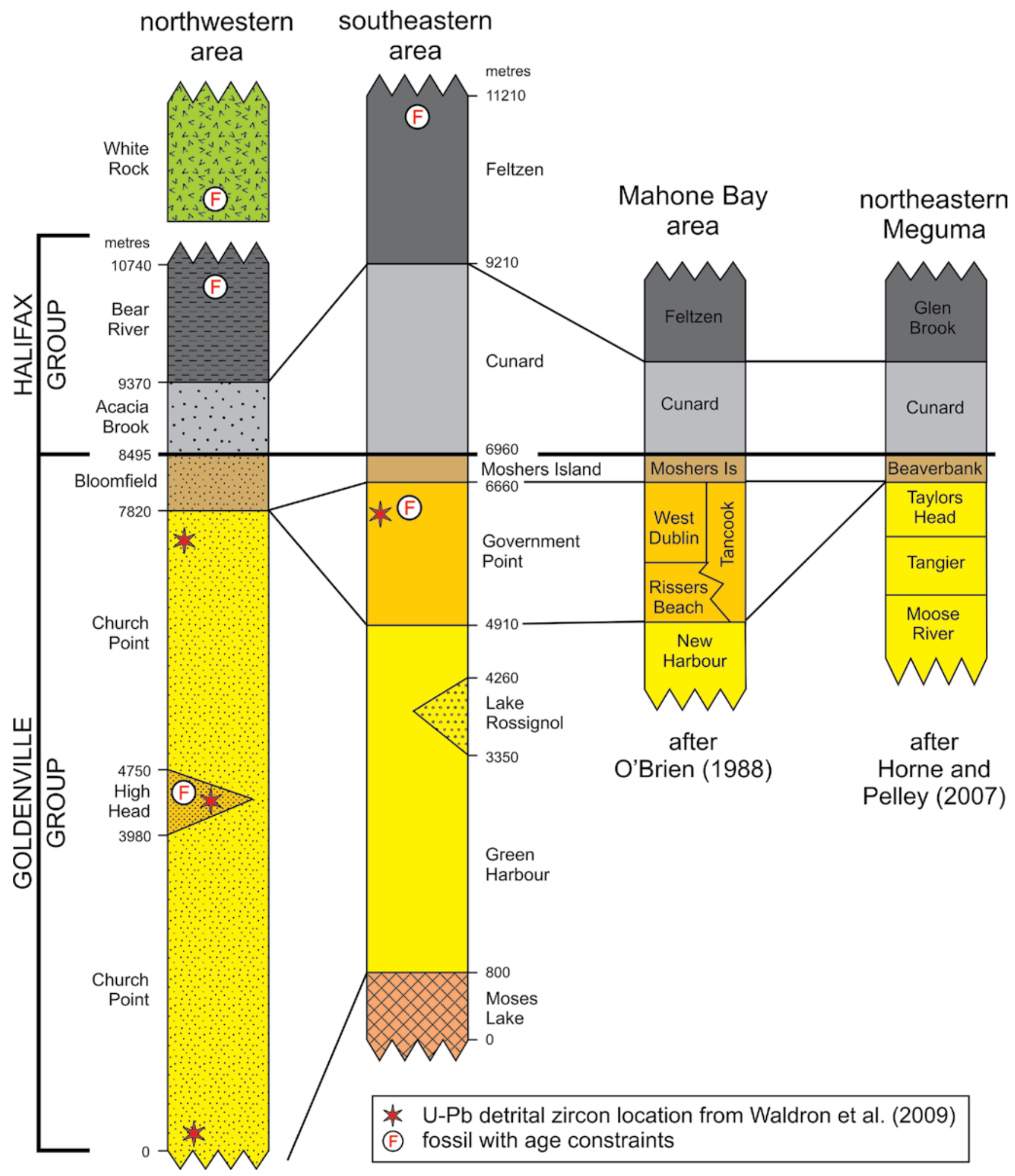

Fig. 3. Stratigraphy in the northwestern and southeastern areas, based on Fig. 2 and references cited in the text. For comparison, the stratigraphic section for the Mahone Bay area and the northeastern part of Meguma are shown. For these sections no stratigraphic thicknesses are implied. 
Rift-related volcanic rocks occur throughout the White Rock Formation (Schenk 1997; Keppie and Krogh 1999; MacDonald et al. 2002; White in press) and may have formed during extension linked to the separation of Meguma from Gondwana (van Staal et al. 1998; White and Barr 2004; van Staal 2007). The Early Devonian Torbrook Formation conformably overlies the White Rock Formation and similarly represents a shallow marine rift environment (Jensen 1975; James 1998; White in press).

Two prominent suites of mafic sills are present in Meguma northwest of the Chebogue Point shear zone (Barr et al. 1983; White et al. 1999; White and Barr 2004). The older suite occurs in both the Goldenville and Halifax groups and locally has peperitic and soft-sediment deformational features indicating that emplacement was contemporaneous with sediment deposition (Barr et al. 1983; White and Barr 2004). In contrast, the younger suite occurs in the White Rock and Torbrook formations as well as in the older units, and is likely SilurianDevonian in age. The similarity in within-plate tholeiitic to alkalic characteristics of both suites of sills, as well as mafic units in the White Rock Formation (MacDonald et al. 2002), indicates that an extensional regime existed along the northwestern margin of Meguma over a period of about $150 \mathrm{~m}$.y. (White and Barr 2004).

All these units were regionally metamorphosed to lower greenschist facies (locally to lower amphibolite facies) and deformed into north- and northeast-trending folds with associated axial planar cleavage during the Middle Devonian, an event now referred to as the Neoacadian Orogeny (van Staal 2007; White et al. 2007). They were intruded by abundant 385-357 Ma peraluminous granitoid rocks (e.g., Clarke et al. 1997; Reynolds et al. 2004; Moran et al. 2007) with narrow, well developed contact metamorphic aureoles containing mineral assemblages characteristic of up to hornblende-hornfels facies (Mahoney 1996; White 2003). Upper Devonian-Carboniferous and Mesozoic rocks unconformably overlie the northern margin of Meguma and also are preserved locally elsewhere in the terrane (Fig. 2).

The nature of the crust underlying Meguma is uncertain. Gneissic rocks in the northern part of the terrane, interpreted previously to represent possible basement units (e.g., Dostal et al. 2006) have been demonstrated to be the result of contact metamorphism of the Goldenville and Halifax groups around Devonian and Carboniferous granitoid plutons (White et al. 2009a, b). Gneissic xenoliths in rare mafic dykes in the northeastern part of the terrane also have been interpreted to represent Meguma basement (Owen et al. 1988; Ruffman and Greenough 1990). Some of the xenoliths are isotopically similar to metasedimentary rocks in the Halifax and Goldenville groups, whereas others have higher epsilon Nd values and preserve an igneous crystallization age of ca. $630 \mathrm{Ma}$ and a metamorphic age of ca. $575 \mathrm{Ma}$ (Eberz et al. 1991; Greenough et al. 1999). Based on these ages and isotopic compositions, the latter xenoliths were inferred to have been derived from underlying Avalonian crust, and have been used as evidence for the argument that Meguma has Avalonian basement (Murphy et al. 2004a, b). Seismic data suggest that the leading edge of Meguma has been thrust over Avalonia (e.g., Keen et al. 1991a, b; Loncarevic et al. 1989), but their original relationship remains unknown.

\section{STRATIGRAPHIC UNITS}

\section{History of Nomenclature}

The two-fold character of metasedimentary rocks in southern Nova Scotia was recognized by Campbell (1863) in the northeastern mainland part of the province. He called the lower division the 'quartzite group' and the upper the 'lower clay slate group'. However, Bailey (1896), working in the southwestern part of the province (current study area), recognized three formations: a lowest 'quartzite division', a middle 'banded argillite division', and an upper 'black slate division'. In the area studied by Campbell (1863), Ami (1900) assigned the names 'Guysborough and Halifax formations' to the 'quartzite' and 'slate', respectively. No name was assigned to the intermediate division recognized by Bailey (1896).

To avoid duplication and confusion in the literature, Woodman (1902) proposed using local Mi'kmaq terms rather than geographic terms for unit designation. He assigned the names 'Lampok' (which means bottom) and 'Seskoo' (which means mud) formations to the designated lower quartzite and the upper slate divisions, respectively. He also placed these formations into the Meguma series. Meguma is also a Mi'kmaq word, root of the native term for their tribe, and hence appropriate for rocks occupying so large a part of Nova Scotia (Woodman 1902). At that time, these terms were not accepted and after numerous consultations with E.R. Faribault and L.W. Bailey, and with their approval, Woodman (1904a, b) proposed the terms Goldenville formation for the lower quartzite division and Halifax formation for the upper slate division. However, Faribault (1903) had used the term 'Goldenville formation', in an earlier publication on gold mining in Nova Scotia. Woodman (1904a, b) retained the use of Meguma series for both formations, a name that later was changed to Meguma Group by Stevenson (1959). Gradually, over the years, the formation names became accepted as formal names and capitalized, although they were never rigorously defined by criteria accepted today for formal unit designations (e.g., North American Commission on Stratigraphic Nomenclature 2005).

Woodman (1904a, b) specified two possible locations for measuring the greatest thickness through the Goldenville Formation in the northeastern part of Meguma. One area near the abandoned Moose River gold mines (NTS 11D/15) with a total thickness of $5100 \mathrm{~m}$ and the other at Fifteen Mile Stream(NTS 11E/01) with a total thickness of $5385 \mathrm{~m}$. Waldron (in Williams et al. 1985) regarded the thicker section as the type section for the Goldenville Formation. Although no type section was designated for the Halifax Formation, Ami (1900) 
and Woodman (1904a, b) considered that the outcrops on the Halifax Peninsula (NTS 11D/12) displayed the greatest exposure. Bell (1929) regarded the rocks exposed at Black River (NTS 21H/01, 21A/16) as the most complete section of the Halifax Formation in the province but Crosby (1962) pointed out that part of this section had been obscured. Waldron (in Williams et al. 1985) regarded the Halifax Formation exposed on the Halifax Peninsula as the type locality.

During the 1980s and 1990s, several members were established locally in the Goldenville and Halifax formations and a "transition zone" was mapped between the two formations in the Mahone Bay area (O'Brien 1986, 1988; Zentilli et al. 1986; Waldron 1987, 1992). The transition zone was informally assigned to the Green Bay formation (O'Brien 1986, 1988). Schenk $(1991,1995)$ proposed correlations of the newly defined members at a number of localities around southwestern Nova Scotia, and in the 1995 paper, proposed elevation of the members to formation status, the Goldenville and Halifax formations to group status, and hence, Meguma to supergroup status. However, the new terminology was not used on the most recent Geological Map of Nova Scotia (Keppie 2000), as it had not been demonstrated that these formations were in fact mappable units, in keeping with the North American Stratigraphic Code (e.g., North American Commission on Stratigraphic Nomenclature 2005). To avoid a long-standing source of ambiguity and confusion in nomenclature arising from having two different meanings for the word Meguma (both a terrane and a group), White and Barr (in press) suggested that the term 'Meguma' be restricted to the name of the pre-Carboniferous terrane and that the term Meguma Supergroup be abandoned. Hence, use of the term 'Meguma Supergroup' is avoided here.

More recent systematic mapping in the southern half of Meguma, combined with detailed aeromagnetic data (e.g., King 2006), has resulted in the establishment of mappable formations (Fig. 2,3). This area is divided into two parts by the Chebogue Point shear zone: the Yarmouth to Digby area along the Fundy coast (here termed the northwestern area) and the Wedgeport to Chester area along the Atlantic coast (here termed the southeastern area). It is noted that the northeastern part of Meguma also has been subdivided locally into formations that appear to correspond approximately with those described here (Ryan et al. 1996; Horne and Pelley 2007; White et al. 2008, 2009a; Horne et al.2009a, b, c, d). However, regional unit definition is not yet possible and hence that area is not included here in this paper.

\section{Northwestern area}

\section{Church Point formation}

In the northwestern area of Meguma, most of the Goldenville Group consists of grey, medium- to thick-bedded metasandstone, locally interlayered with green, cleaved metasiltstone, and rare black slate (Fig. 4a). This thick (>8000 m) metasandstone-dominated unit has been named the Church
Point formation (White 2008b). The formation is well exposed along the coast from Salmon River to Cranberry Point (Fig. 2), which can be designated as the reference section, following the criteria established in the North American Commission on Stratigraphic Nomenclature (2005). The base is not exposed but the lowermost strata are seen in the core of the Black Point anticline. Large (up to $50 \mathrm{~cm}$ - long axis) brown carbonate-rich concretions are locally abundant. Metasandstone beds typically are laminated to cross-laminated or display convolute laminations near the top but the lower parts are devoid of sedimentary structures, possibly due to fluidization by water escape. Sole marks such as flute and load casts are locally common. Such beds have been described elsewhere in the Goldenville Group and interpreted to be the result of high-concentration turbidity currents (e.g., Waldron and Jensen 1985; Waldron 1987). Limited paleocurrent data from the Church Point formation indicate southward paleoflow (Waldron et al. 2009), in contrast to flow to the northeast reported elsewhere in the Goldenville Group (Schenk 1981; Waldron and Jensen 1985; Waldron 1988). The stratigraphically lowest and highest metasandstone beds in the formation yielded concordant detrital zircon ages of $544 \pm 18$ and $529 \pm 19 \mathrm{Ma}$, respectively, limiting the maximum depositional age of the base and top of the formation (Waldron et al. 2009), so that the unit could be as old as the Ediacaran of the uppermost Neoproterozoic.

The metasandstone is typically very fine- to mediumgrained and poorly sorted. Although the original mud matrix has recrystallized to a mixture of sericite, chlorite, and epidote, subangular to rounded sand-sized detrital grains are present still in many samples. However, locally where regional or contact metamorphism is at higher grades, the matrix contains abundant coarse muscovite and biotite, and individual sandsized grains exhibit granoblastic textures. The composition of the metasandstone is dominantly feldspathic wacke with subordinate quartz- and lithic wacke and rare feldspathic arenite (White 2010). Coarse sandstone to granule conglomerate beds occur locally in the lower half of the Church Point formation where they form lenses ( 1 to $2 \mathrm{~m}$ by 10 to $20 \mathrm{~cm}$ thick) with irregular, erosive bases and flat tops, and probably represent channel fills. They are matrix supported, poorly to well sorted, and massive to normally graded. Lithic fragments are dominantly polycrystalline quartz (quartzite) with subordinate volcanic clasts of pilotaxitic basalt and andesite, porphyritic rhyolite and dacite, and recystallized felsic crystal tuff (White and Barr in press). Rare plutonic fragments are tonalitic in composition (quartz and euhedral plagioclase).

About $4 \mathrm{~km}$ up-section in the Church Point formation near High Head, on the southeastern limb of the Black Point anticline (Fig. 2), a thick $(<1 \mathrm{~km})$ interval of greyish-green, parallel-laminated, (rarely cross-laminated), magnetite-rich, metasiltstone to slate (Fig. 4b) has been termed the High Head member (White et al. 2005a, b). The base of the member is marked by an abrupt decrease in abundance of metasandstone beds whereas the upper contact is marked by an increase in metasandstone beds. The High Head member metasiltstone locally contains a distinctive trace fossil assemblage ranging 

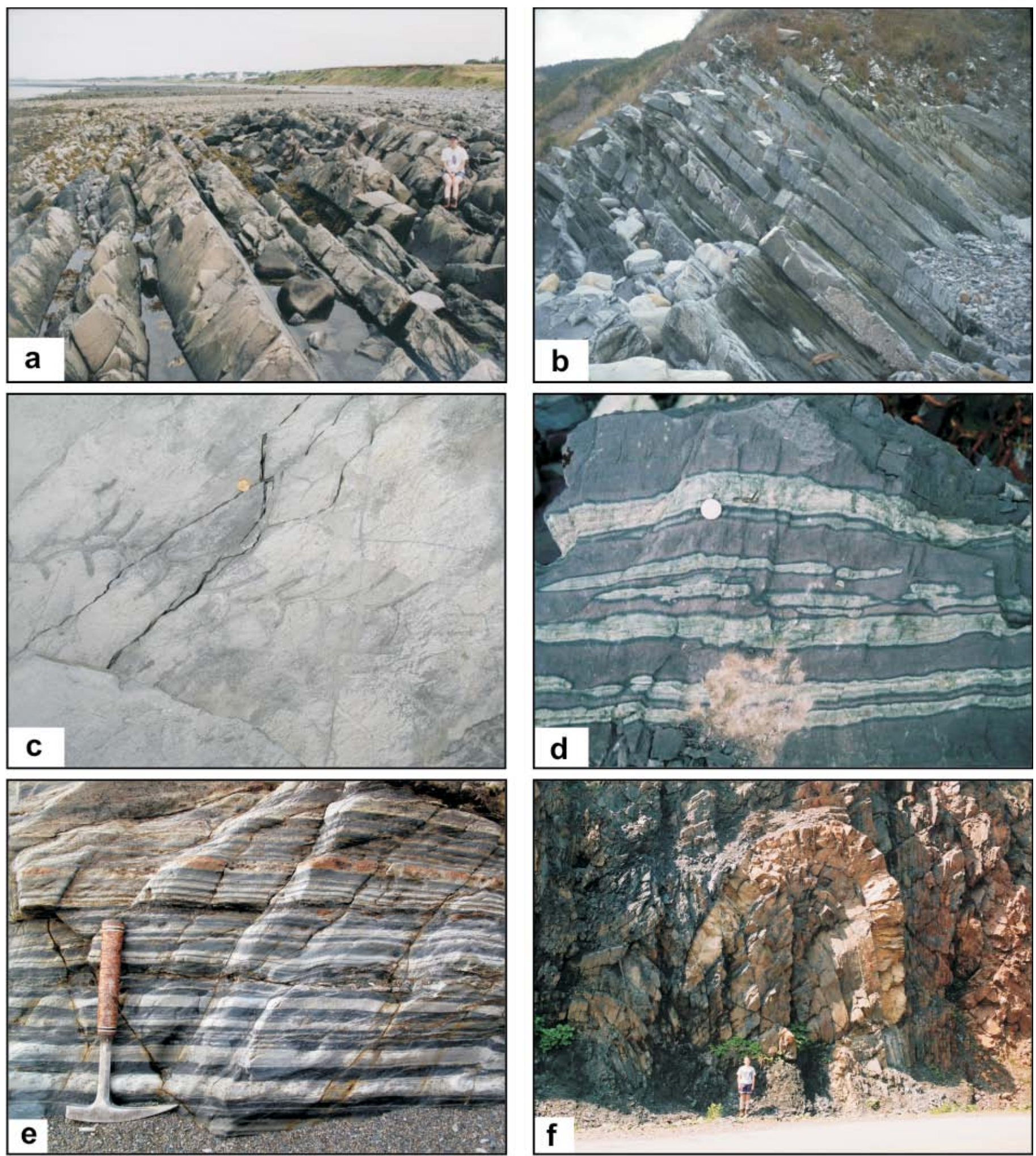

Fig. 4. Typical exposures of units in the northwestern area. (a) Thickly bedded metasandstone of the Church Point formation near Church Point (Location UTM 729150E, 4908906N; 19T). (b) Thinly bedded metasiltstone of the High Head member at High Head (Location UTM 727767E, 4870898N; 19T). (c) One of the many trace fossils in the High Head member. (d) Thinly bedded metasiltstone of the Bloomfield formation (Location UTM 278221E, 4941101N; 20T. (e) Interbedded slate and finegrained metasandstone of the Bear River formation (Location UTM 724008E, 4890058N; 19T). (f) Folded slate and metasiltstone of the Bear River formation containing a folded mafic sill (Location UTM 287017E, 4943652N; 20T). 
from irregular to meandering trails on bed surfaces (Fig. 4c), including the Early Cambrian Oldhamia ichofossils (White et al.2005b). These trace fossils suggest a Nereites ichnofacies indicative of a deep-water environment (Gingras et al. in press). The matrix has typically recrystallized to a mixture of sericite, chlorite, and epidote with scattered grains of quartz and plagioclase. The composition of the metasandstone is dominantly feldspathic wacke (White 2010). The high magnetite content has resulted in a relatively high aeromagnetic response with respect to the rest of the Church Point formation, allowing the High Head member to be traced under glacial till into inland areas where it pinches out (Fig. 2). This dominantly finegrained succession likely was deposited from suspension in a relatively quiet abyssal plain setting, although the presence of local cross-laminations indicates the existence of near-bottom currents.

The High Head member includes several massive metasandstone beds in its central part. They are up to $3 \mathrm{~m}$ in thickness, displaying parallel lamination and normal grading with coarse-grained sand lenses and tabular cross-bedding. Like the metasandstone in the rest of the Church Point formation, these beds are interpreted to be the result of episodic high-concentration turbidity currents. The youngest detrital zircon extracted from the uppermost metasandstone bed has an age of $537 \pm$ $15 \mathrm{Ma}$, indicating the maximum depositional age and consistent with similar (within error) ages obtained from the base and top of the formation (Waldron et al. 2009).

Although a few minor faults cut the member, a complete stratigraphic succession is exposed along the coast at High Head (Fig. 2) where the type section is defined (e.g., Gingras et al. in press).

\section{Bloomfield formation}

The upper part of the Goldenville Group in the northwestern area (northwest of the Chebogue Point shear zone; Fig. 2) is the metasiltstone-dominated Bloomfield formation (Bloomfield member of White et al. 1999, 2001 and Horne et al. 2000). This unit is exposed on the limbs of the regionally extensive Black Point anticline. It is typically 200 to $400 \mathrm{~m}$ thick on the southeastern limb, but increases to $1000 \mathrm{~m}$ thick on the northwestern limb. The variation in thickness is interpreted to be due to transposition and related thickening by the Cape St. Marys and Chebogue Point shear zones (Culshaw and Leisha 1997; White et al. 2001).

The Bloomfield formation consists of mainly distinctly banded maroon and green, thin- to medium-bedded metasiltstone to slate (Fig. 4d). Some of the thin metasiltstone beds display small-scale cross-lamination. Along strike to the southwest where regional metamorphism is at biotite and garnet grade, the metasiltstone is more phyllitic to schistose and light greyish-green. Thin $(<10 \mathrm{~cm}$ thick $)$ metasandstone layers are rare and are typically very fine grained and poorly to moderately sorted. The composition of the metasandstone is dominantly feldspathic wacke (White 2010). Deposition of the Bloomfield formation may have been from dilute silty to muddy turbidity currents.

A complete section of the Bloomfield formation is not exposed. The best exposures, however, are in an abandoned quarry near Bloomfield and along the coast at Cranberry Point (Fig. 2). The section at Cranberry Point could be designated as the type section because a sharp contact between metasiltstone of the Bloomfield formation and underlying massive metasandstone of the Church Point formation is well exposed. However, the grade of metamorphism is sufficiently high that the original sedimentary features have been obliterated. In contrast, in the abandoned quarry the contact with the underlying Church Point formation is not exposed but grade of metamorphism is low and the original lithologies and textures are better preserved. The thick section exposed in Meteghan River on the northwestern limb of the Black Point anticline could also be considered as a type section but at this location the rocks are more deformed and structurally complex.

Although originally assigned to the lowermost part of the Halifax Group, regional mapping has resulted in reassignment to the Goldenville Group (White 2008b) (see Discussion).

\section{Acacia Brook formation}

The Acacia Brook formation (Acacia Brook member of White et al. 1999) is the basal unit in the Halifax Group (see Discussion) in the northwestern area and forms two distinct areas of outcrop: Cape St. Marys and Bear River (Fig. 2, 3). As measured near Bear River, the formation is about $820 \mathrm{~m}$ thick and consists of grey to dark grey, laminated slate with minor, thin ( $<5 \mathrm{~mm}$ thick) beds and lenses of light grey metasiltstone, as well as beds of cross-laminated fine- to mediumgrained metasandstone up to $20 \mathrm{~cm}$ thick. The metasandstone is dominantly feldspathic wacke but is more quartz-rich than the metasandstone beds in the High Head member and Bloomfield formation (White 2010). Sulphide minerals (pyrite, pyrrhotite, and arsenopyrite) are locally abundant. Trace fossils are rare. The slate-metasiltstone and metasandstone are interpreted as low- and high-concentration turbidites, respectively. The abundance of graphite and sulphide minerals suggest deposition under anaerobic sea-floor conditions during a period of basin-wide stagnation (Waldron 1987, 1992).

The outcrop along Sissiboo River, east of Weymouth (Fig. 2), provides the best exposure of the Acacia Brook formation and is designated the type section. Here the contact is sharp and conformable with the underlying Bloomfield formation (Horne et al. 2000). However, farther to the southwest the lower contact with the Bloomfield formation is tectonic and marked by the Cape St. Marys and Chebogue Point shear zones (Culshaw and Leisha 1997; White et al. 2001).

\section{Bear River formation}

Like the Acacia Brook formation, the Bear River formation (Bear River member of White et al. 1999; Sissiboo member of 
Horne et al. 2000) outcrops in two areas (Fig. 2). It forms the upper unit in the Halifax Group west of the Chebogue Point shear zone, separated by an inferred regional disconformity from the overlying Late Ordovician and younger White Rock and Torbrook formations (Fig. 3). The most continuous section of the Bear River formation exposed along the lower part of Bear River (Fig. 2) in the shallow southeastern limb of the Black Point anticline is designated as the type section (White et al. 1999). Here the minimum thickness of the formation is about $1370 \mathrm{~m}$. The Bear River formation consists predominantly of light to dark grey, well laminated, cleaved metasiltstone, with minor, thin $(<5 \mathrm{~cm}$ thick) slate beds (Fig. $4 \mathrm{e})$. These metasiltstone beds are a characteristic feature of this formation and are typically discontinuous, and lenticular with cross-laminations. Grey, massive, fine-grained metasandstone beds, up to $50 \mathrm{~cm}$ thick, are locally present. Like metasandstone in the older units, its composition is dominantly feldspathic wacke (White 2010).The metasiltstone and metasandstone typically contain abundant detrital muscovite. Carbonate-rich lenses and beds (up to $5 \mathrm{~cm}$ thick) locally occur. Pyrite and arsenopyrite are less common than in the underlying Acacia Brook formation but locally occur in beds up to $2 \mathrm{~cm}$ thick. The lower contact of the Bear River formation is gradational and placed above the highest occurrence of thick cross-bedded metasandstone of the Acacia Brook formation.

Primary sedimentary structures are common in the Bear River formation and include cross-laminations and gradedbedding, groove, tool, and load marks, ripples, and smallscale slump features. Fossil occurrences are generally sparse, although trace fossils (burrowing and grazing) and bioturbated layers are common. Trace fossils are interpreted to be of the Zoophycos ichnofacies formed in mainly silty turbidites in an oxygen-rich, upper slope to muddy outer shelf environment (e.g., Schenk 1997). Early Tremadoc acritarch microfossils were reported by Doyle (1979) and confirmed by Palacios et al. (2009). The upper part of the Bear River formation locally contains the Early Ordovician graptolite Rhabdinopora flabelliformis (White et al. 1999) (Fig. 4f).

\section{Southeastern area}

\section{Moses Lake formation}

The lowermost strata exposed in the southeastern area were named the Moses Lake formation by White (2008b) and occur in the cores of north- and northeast-trending anticlines in the west in and around the town of Wedgeport (Fig. 2). There, the formation is exposed in scattered outcrops and because of its relatively high aeromagnetic response with respect to the overlying Green Harbour formation, can be traced into till-covered inland areas as well as into the offshore (White 2003). Although the base of the formation is not exposed, the minimum thickness is about $800 \mathrm{~m}$. A designated type-section is difficult to erect given the scattered distribution of outcrop and lack of continuous exposures. However, the outcrops in and around Moses Lake are indicative of the lithologies in this formation.
The Moses Lake formation consists mainly of grey, thinlyto medium-bedded metasandstone, interlayered with minor green, cleaved metasiltstone. The composition of the metasandstone ranges from feldspathic to quartz wacke with rare quartz arenite (White 2010). Beds of black, magnetic slate with abundant sulphide minerals (pyrite, pyrrhotite, and arsenopyrite) are a distinctive feature of the formation. Large (up to $50 \mathrm{~cm}$ - long axis), light-grey to buff pink, calc-silicate concretions and thin calc-silicate beds $(<5 \mathrm{~cm})$ are locally abundant in the metasandstone. Sedimentary structures are common and include cross-laminations, graded bedding, and ripple marks. The clastic lithologies are typically spotted with biotite and cordierite as a result of contact metamorphism by the Wedgeport Pluton (MacLean et al. 2005). The very finegrained, well-sorted metasandstone-slate package has characteristics typical of classical distal tubidites (e.g., Mutti 1992).

\section{Green Harbour formation}

The Green Harbour formation (New Harbour member of O'Brien 1988; Green Harbour member of White 2005) is the most extensive unit in the southeastern area and occurs in the cores of northeast-trending anticlines (Fig. 2). Although a complete, uninterrupted section does not exist, the good exposures along the coast of Green Harbour are designated as the type section (Fig. 2). The base of the formation is placed at the top of the most prominent magnetic slate bed in the underlying Moses Lake formation that coincides also with an upward increase in metasandstone grain size and feldspar content (White 2010). The formation is about $4000 \mathrm{~m}$ thick and is dominated by grey, thick-bedded, medium-grained metasandstone (Fig. $5 \mathrm{a})$. The metasandstone is locally interbedded with minor green, cleaved metasiltstone and rare black rusty slate. Large (up to $50 \mathrm{~cm}$ - long axis) brown carbonate-rich concretions and beds $(<10 \mathrm{~cm}$ thick) are locally abundant (Fig. 5b). Most metasandstone beds are internally featureless but typically laminated to cross-laminated and rippled in the uppermost $10 \mathrm{~cm}$. The composition of the metasandstone ranges from dominantly feldspathic to quartz wacke with subordinate feldspathic to quartz arenite (White 2010). Like metasandstone in the Church Point formation, the metasandstone displays de-watering structures and was likely the product of deposition from high-concentration turbidity currents (Waldron 1987, 1992; O’Brien 1988; Schenk 1997). Rare bedding-plane grazing trace fossils are present. Paleocurrent data indicate a northwestward paleoflow (Waldron 1987, 1988; Waldron et al. 2009), in contrast to the more north-directed paleoflow reported by Schenk (1981). The Green Harbour formation displays uniform low aeromagnetic response throughout the area (King 2006).

The Lake Rossignol member was recognized recently as a distinct unit in the upper part of the Green Harbour formation in the northeastern part of the southern area (White 2006). The type section of the member is exposed in scattered outcrops on the shores of Lake Rossignol; however, a quarry near Middlewood displays the typical lithologies of the unit. It is 

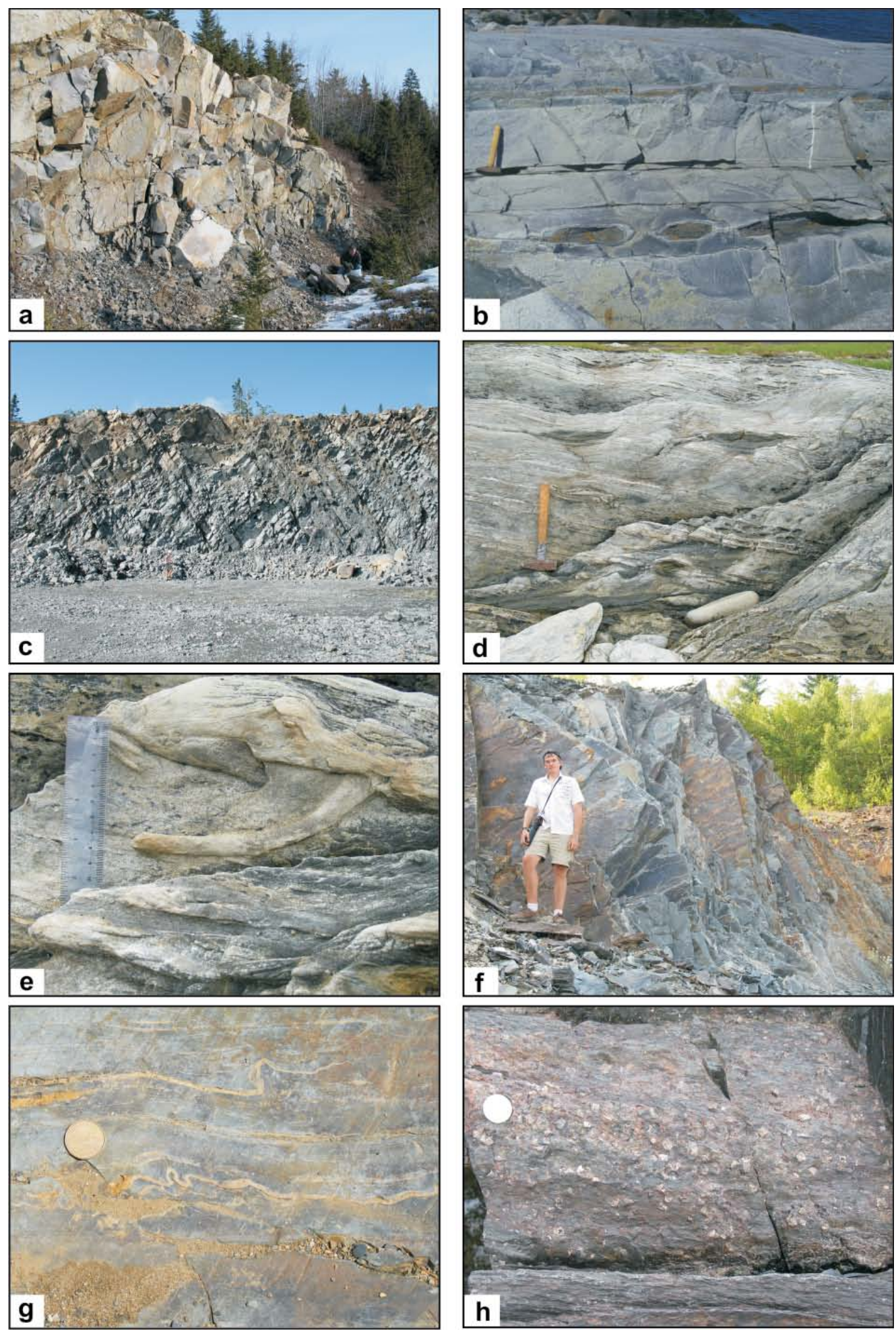

Fig. 5. Typical exposures of units in the southeastern area. (a) Thickly bedded metasandstone of the Green Harbour formation (Location UTM 353592E, 4869167N; 20T). (b) Calc-silicate nodules and beds in metasandstone beds of the Green Harbour formation (Location UTM 332969E, 4839508N; 20T). (c) Thickly layered metasandstone of the Lake Rossignol member (Location UTM 375721E, 4894301N; 20T). (d) Metasiltstone with thin metasandstone beds of the Government Point formation (Location UTM 378611E, 4887198N; 20T). (e) One of the many burrowing trace fossils in the Government Point formation (Location UTM 378611E, 4887198N; 20T). (f) Purple and grey slate and metasiltstone of the Moshers Island formation (Location UTM 368627E, 4945036N; 20T). (g) Thin, pink coticule beds in a metasiltstone of the Moshers Island formation (Location UTM 356308E, 4877283N; 20T). (h) Large cubes of pyrite in a slate bed of the Cunard formation (Location UTM 353099E, $4903501 \mathrm{~N} ; 20 \mathrm{~T})$. 
approximately $1 \mathrm{~km}$ thick, and consists of rhythmically layered ( 2 to $3 \mathrm{~m}$ thick) grey, fine-grained metasandstone (Fig. $5 \mathrm{c})$. Many of the beds have conglomeratic bases with thin $(<20$ $\mathrm{cm})$ well laminated metasiltstone at the top. The composition of the metasandstone ranges from dominantly feldspathic to quartz wacke with subordinate feldspathic to quartz arenite (White 2010). Large, up to $2 \mathrm{~cm}$ wide, pyrite cubes are locally abundant in the metasandstone. The base of the unit appears to be erosional into underlying metasandstone of the Green Harbour formation and is composed of poorly sorted, granule to cobble metaconglomerate in a coarse-grained metasandstone matrix. The top of the unit is not exposed. The Lake Rossignol member displays relatively uniform high aeromagnetic response throughout the area but is not laterally extensive and 'pinches-out' to the southeast (King 2006). Like metasandstone units in the rest of the Green Harbour formation, these beds are probably the result of high-concentration turbidity currents (e.g., Waldron 1992) but their coarser grain size suggests that they are more closely related to channelized debrisflows.

\section{Government Point formation}

In areas of low metamorphic grade, the Government Point formation is typically composed of grey, thinly to thickly bedded metasandstone, rhythmically laminated green to greyish-green metasiltstone, and black slate (Fig. 5d). As in the Green Harbour formation, calc-silicate nodules are common in the metasandstone and are locally manganese-rich. In the Kejimujik area the formation is dominantly well-laminated green to greyish-green to purple metasiltstone with minor metasandstone. In this area manganiferous staining along bedding planes and fractures is common. At higher regional metamorphic grade and around the margins of plutons, the more pelitic beds are composed of andalusite-garnet-sillimanite schist, granofels, and migmatite. In the Kejimujik area rare coticules were observed in contact metamorphic aureoles. The composition of the metasandstone ranges from dominantly feldspathic to quartz wacke with subordinate feldspathic to quartz arenite (White 2010). A bioclastic limestone near the top of the formation in the area mapped by O'Brien (1988) farther to the east yielded a Middle Cambrian trilobite faunule (Pratt and Waldron 1991). A pelmatozoan-bearing calc-silicate nodule at a similar stratigraphic level to the west was reported by White (2006). Grazing and burrowing trace fossils (Fig. 5e) are abundant (Waldron 1987; White 2005, 2006). Rare quartzpebble conglomerate beds form deeply scoured channels that can be traced locally for 10's of meters along strike. They are probably the result of high-concentration turbidity currents (e.g., Waldron 1987). The type section is well exposed along the coast at Government Point where the maximum total thickness of the formation is about $1750 \mathrm{~m}$.

The contact between the Government Point formation and underlying Green Harbour formation is marked by an increase in more silty interbeds and thinning of the massive metasand- stone beds over an interval 100 to $300 \mathrm{~m}$ and the contact is placed where the silty interbeds exceed $30-40 \%$. The contact also coincides with a higher positive aeromagnetic response that can be regionally traced in the southeastern area. Overall, the Government Point formation is characterized by thin, alternating bands of high and low aeromagnetic response that reflect the high magnetite content of the interlayered silty beds.

To the northeast in the Mahone Bay area (Fig. 2) the equivalent stratigraphic level was assigned to the Tancook member (O’Brien 1985; Waldron 1987) whereas in the Lahave Islands area (Fig. 2) the lower 100 to $300 \mathrm{~m}$ was assigned to the Rissers Beach member and the upper part to the West Dublin member (O’Brien 1985). These members, including the overlying Moshers Island member (see Discussion section) were included in the informally defined Green Bay formation of O'Brien (1985).

\section{Moshers Island formation}

The Moshers Island formation (Snug Harbour Sandstone of O'Brien 1986; Moshers Island member of O’Brien 1988) is a thin $(<300-500 \mathrm{~m}$ wide) unit of green to greenish-grey to grey to purple, well laminated metasiltstone to slate, interlayered with minor, fine-grained, 1 to $10 \mathrm{~cm}$-thick metasandstone beds (Fig. 5f). A characteristic feature in this unit is the presence of steel-blue manganiferous nodules and laminations. At slightly higher metamorphic grades these nodules and laminations form thin (up to $10 \mathrm{~cm}$ thick), pink coticule beds and lenses due to the growth of spesssartine garnet (Fig. $5 \mathrm{~g})$. Carbonate laminations and concretions are locally present and some contain rare ooid-like structures. Rare burrowing and grazing trace fossils have been observed. Some of the best exposures of the formation are on Moshers Island, herein designated as the type section, but the most complete section is located on Big Tancook Island (e.g., O'Brien 1985; Waldron 1987). The contact with the underlying metasandstone-dominated Government Point formation is gradational. However, following the criteria established by O'Brien (1988) the contact is placed at the top of the highest decimetre-thick metasandstone in the underlying Government Point formation. Hence, this unit is included in the Goldenville Group, rather than in the Halifax Formation as done by earlier workers (O'Brien 1986, 1988; Waldron 1992; Schenk 1995). An additional argument in favour of including the unit with the Goldenville Group is its sharp and easily mappable contact with the overlying Cunard formation (described below), from which it is lithologically distinct (see Discussion for further details).

Sedimentary structures are generally absent, which led Waldron $(1987,1992)$ to suggest deposition in relatively deep, generally quiet-water conditions. However, the presence of ooids suggests that the water depth may not have been great, unless the ooids were transported from shallower depths. Metasandstone beds in this unit have not yet been sampled for petrographic analysis. 


\section{Cunard formation}

The Cunard formation (Cunard member of Hall 1981 and O'Brien 1986, 1988) consists predominantly of black to rustbrown slate with thin beds and lenses of minor black metasiltstone. Cross-laminated, fine- to medium-grained, poorly sorted, pyritiferous metasandstone beds, up to $30 \mathrm{~cm}$ thick, are locally present (Fig. 5h). The composition of the metasandstone is dominantly feldspathic wacke with subordinate quartz wacke (White 2010). It locally contains abundant pyrite, arsenopyrite, and pyrrhotite beds up to $5 \mathrm{~cm}$ thick. Trace fossils are rare. The formation is about $2250 \mathrm{~m}$ thick. The best exposures are along the Atlantic coast in and around the Ovens area farther to the east where O'Brien (1988) established the type section.

Like the stratigraphically equivalent Acacia Brook formation in the northwestern area, the slate-metasiltstone and metasandstone are interpreted as low- and high-concentration turbidites (e.g., Stow et al. 1984). The abundance of graphite and sulphide minerals suggest deposition under anaerobic sea-floor conditions during a period of basin-wide stagnation (cf., Waldron 1992; Schenk 1997). However, as in the underlying Moshers Island formation, ooid-rich thin beds are present which suggests that some parts may have been deposited in more shallow water or that these micro-structures were transported into deep water.

The basal contact of the Cunard formation with the underlying Moshers Island formation is exposed in several localities. It is conformable, sharp, and placed at the first appearance of black rusty slate.

\section{Feltzen formation}

The overlying Feltzen formation (Feltzen member of Hall 1981 and O'Brien 1985, 1986, 1988) occurs in the cores of northeast-trending synclines in the Mahone Bay, Sherbrook Lake, and Maitland Bridge areas (Fig. 2). It is composed of light grey to blue-grey slate, rhythmically interlayered with laminated to thinly bedded, fine-grained metasandstone. The best exposure of this formation is near Blue Rocks (Fig. 2) in the area mapped by O'Brien (1988) and this location is considered the type section. However, excellent outcrops occur in the Mersey River near Maitland Bridge although access is restricted as many of the outcrops are in the Kejimkujic National Park. In contrast to the Cunard formation, abundant worm burrows are a characteristic feature of the Feltzen formation (O'Brien 1988), as well as numerous other trace fossils. The lower boundary with the Cunard formation was considered gradational, and placed at the first occurrence of black slate (e.g., O'Brien 1988). This position also correlates with the disappearance of sulphide minerals. The stratigraphic top is not exposed, and therefore an estimated minimum thickness is about $2 \mathrm{~km}$. Rare graptolites indicate an Early Ordovician age (e.g., Cumming 1985). Like the Bear River formation, the Feltzen formation likely formed as mainly silty turbidites in an oxygen-rich, shelf environment (e.g., Schenk 1997).

\section{DISCUSSION}

\section{Formal vs Informal Names}

Establishing stratotypes or type sections is a fundamental concept for formalizing stratigraphic units. It allows the original observations to be verified or elaborated and is one of the main criteria is establishing formal units (North American Commission on Stratigraphic Nomenclature 2005). The upgrading of the Goldenville and Halifax formations to group status (e.g., Schenk 1995) and demonstration of mappable formations within these groups (as documented here) dictates that type sections suggested for the Halifax and Goldenville groups when they were formations are no longer appropriate (c.f. Waldron in Williams et al. 1985). However, such change is difficult to implement within the confines of the North American Commission on Stratigraphic Nomenclature (2005, Article 22c) which states that a type section never changes: "The definition and name of a lithstratigraphic unit are established at a type section (or locality) that, once specified, must not be changed. If the type section is poorly designated or delimited, it may be redefined subsequently."

The type section for the "Goldenville Formation" was considered by Waldron (in Williams et al. 1985) to be at Fifteen Mile Stream where Woodman (1904a, b) measured the greatest thickness through the formation. However, recent mapping in that area (White et al. 2009a) showed that this type section may only represent the upper part of the Goldenville Group in the northeastern part of Meguma. Likewise, based on recent mapping in the Annapolis Valley (White in press), the type section for the former Halifax Formation on the Halifax Peninsula (Waldron in Williams et al. 1985) represents only the lower part of the newly defined Halifax Group with several younger formations absent. Although the originally specified type sections may be the thickest, although even that is unlikely, they are incomplete as they are not representative of all of the stratigraphic units in the Goldenville and Halifax groups.

The North American Commission on Stratigraphic Nomenclature (2005, Article 22c) allows the establishment of a principal reference section or several reference sections to supplement, but not to supplant, the type section (Article $8 \mathrm{e})$. In the northwestern area of the present study, such a reference section can be established for the Goldenville Group along the coast from Salmon River to Cranberry Point along the southeastern limb of the Black Point Anticline (Fig. 2). In contrast, in the southeastern area, no adequate single reference section can be established for the Goldenville Group due to lack of appropriate exposure. However, most of the individual, newly defined formations in the Goldenville Group in that area have recognized type sections (described above) which may be considered to constitute a composite-stratotype (e.g., North American Commission on Stratigraphic Nomenclature 2005, Article 8d, e).

With respect to the Halifax Group, no single section in the study area is adequate for establishing a reference section. However, recent mapping in the Wolfville area (White in press) 
showed that Bell (1929) was correct in that the rocks exposed at Black River provide the most complete (and representative) section of the Halifax Group in the province. Although parts of the section are obscured (e.g., Crosby 1962), it should be noted that the original type sections for the Goldenville and Halifax formations also have parts that are obscured and folded.

Many of the criteria established by the North American Commission on Stratigraphic Nomenclature (2005) for defining formal formations have been followed in this paper, and detailed geological maps (1:50 000 scale) are in preparation by the Nova Scotia Department of Natural Resources. However, providing measured stratigraphic sections, as required by the Code, for formations that are thousands of metres in thickness is clearly beyond the scope of this paper, or indeed the mandate of the Department of Natural Resources. Hence the newly defined formations must be considered as informal units, until such information can be generated, or (as in the case of the previous terminology) acceptance by the geological community results in gradual conversion to capitalization of the names.

\section{Position of the Goldenville Group-Halifax Group Boundary}

The position of the contact between the former Goldenville and Halifax formations has not been consistent over the years. Faribault (1914) and Taylor $(1967,1969)$ used the highest exposed bed of 'greywacke' as the position for the contact, although the thickness of that bed was not reported, whereas Schenk (1970) used a sand/shale ratio to define the boundary. Faribault (1908) showed several beds of limestone at the base of the Halifax Formation on the east side of Halifax Harbour. However, on the west side of the harbour, King (1935) placed similar beds of limestone in the top of the Goldenville Formation. Crosby (1962) was unable to define a clear division between the Halifax and Goldenville formations in the Wolfville area, although he recognized a downward increase in silica content towards the base of the Halifax Formation. These interpretations resulted in considerable variation in the location of the contact. Adding to the confusion, Schenk (1975) and Harris and Schenk (1975) suggested that the Goldenville and Halifax formations are partly coeval.

Rocks equivalent to the Government Point and Moshers Island formations as defined here typically have been included in the Halifax Formation (e.g., Faribault et al. 1938a, b; Taylor 1967). However, in the Mahone Bay area, O’Brien (1988) recognized that these units as distinct from both the Halifax and Goldenville formations and placed them in a separate Green Bay formation, which he correlated with the GoldenvilleHalifax Transition Zone (GHT) as defined by Zentilli et al. (1986). Waldron $(1987,1992)$ placed the Goldenville-Halifax boundary immediately above the last occurrence of decimetrebedded metasandstone at the base of the Moshers Island formation in the lower formation in the transition zone.

In contrast, White $(2005,2006)$ and White et al. (2007) suggested that the Government Point and Moshers Island formations are more closely linked to the Goldenville Group than to
Halifax Group. This interpretation was based on (1) the similar appearance of metasiltstone and slate in the Government Point and Moshers Island formations, in contrast to the black sulphide-rich slate in the Cunard formation, (2) the presence of abundant metasandstone beds in the Moshers Island formation, similar to those in the underlying Government Point formation, but thinner than and not similar to those in the Cunard formation, and (3) the gradual increase in Mn-content from the Government Point to Moshers Island formations, in contrast with the low Mn content in the Cunard formation (White 2010; White and Barr in press). The interpretation is further supported by opinions of previous workers who also considered the rocks of the GHT to correlate more closely with those in the Goldenville Group than those in the Halifax Group (e.g., Binney et al. 1996; Zentilli et al. 1986; Sangster 1990). During regional mapping, it was apparent to the author that the contact between the Moshers Island and Cunard formations is the most recognizable and easily mapped boundary in the Goldenville and Halifax groups in southwestern Nova Scotia, and hence it is the most logical position for the group boundary.

\section{Government Point Formation vs Green Bay Formation}

O'Brien $(1985,1986,1988)$ mapped the Mahone Bay area east of the present study area. He recognized a major unit between the Goldenville and Halifax formations, which he termed the Green Bay formation and correlated with the GHT. The Green Bay formation comprises four members: Rissers Beach, West Dublin, Tancook, and Moshers Island.

The basal Rissers Beach and overlying West Dublin members are equivalent to the Government Point formation defined in this study. Although elements of these members are recognized in the Government Point formation, lateral facies and thickness changes make it difficult to map their lateral continuity, a feature also noted by O'Brien (1988). Farther to the east, the Rissers Beach member could not be recognized and the West Dublin member becomes instead the Tancook member (O'Brien 1986, 1988; Waldron 1987). In this study, the Moshers Island member has been upgraded to formation status as a result of its wide distribution and distinctive composition.

Because the Rissers Beach, West Dublin, and Tancook members are mappable units in the Mahone Bay area, they are retained in the current stratigraphic scheme. However, the term Green Bay formation is not used and these members are included instead in the Government Point formation.

\section{Significance of Stratigraphic Differences across the Chebogue Point Shear Zone}

The Chebogue Point shear zone records the effects of Carboniferous deformation and was previously considered similar to other ca. $325 \mathrm{Ma}$ shear zones such as the Cranberry Point shear zone in southwestern Nova Scotia (Culshaw and Liesa 1997; Culshaw and Reynolds 1997; Moynihan 2003). 
However, as a result of regional mapping (White et al 2001; White 2003), it became clear that unlike the other shear zones, stratigraphic differences occur across the Chebogue Point shear zone. This shear zone is a wide north-south to northeast-trending belt located along the contact between the White Rock and Green Harbour formations, and incorporating a thin sliver of the Acacia Brook formation (Fig. 2). Near the southern end, the shear zone juxtaposes chlorite-grade metamorphic rocks of the Green Harbour formation and staurolite-grade metamorphic rocks of the Acacia Brook and White Rock formations (Hwang 1985; Moynihan 2003; White 2003). In its northern part it juxtaposes the Acacia Brook and Green Harbour formations before disappearing as a brittle feature into the South Mountain Batholith. At Chebogue Point, kinematic indicators suggest west-side-up dip-slip motion (Culshaw and Liesa 1997; Moynihan 2003) whereas the offshore extension on Seal Island indicates dextral strike-slip motion (Moran et al. 2007).

West of the Chebogue Point shear zone (termed the northwestern area in the present study) the Halifax Group is disconformably overlain by rift-related, shallow marine volcanic and sedimentary rocks of the Silurian White Rock Formation and equivalent units and the Early Devonian Torbrook Formation (Jensen 1975; Lane 1975, 1981; Bouyx et al. 1997). These younger formations are not present southeast of the shear zone. In addition, the mafic sills that are prominent in the northwestern area (Barr et al., 1983; White et al., 1999; White and Barr, 2004) are not present southeast of the shear zone.

Based on lithological, mineralogical, and chemical features, the formations defined in the Goldenville and Halifax groups also do not appear to correlate across the Chebogue Point shear zone, an observation supported by aeromagnetic data (King 2006). The Goldenville and Halifax groups in the northwestern area have a lower quartz/feldspar ratio in psammitic rocks and contain more volcanic debris than those in the southeastern area (White 2010). These differences may indicate that the northwestern area was closer to the source, whereas the sediments deposited in the southeastern area may have travelled farther and been deposited in deeper water. This interpretation is consistent with the high concentration of manganese in the Moshers Island formation in the southeastern area compared to that in the stratigraphically equivalent Bloomfield formation in the northwestern area (White and Barr, in press). The manganiferous sediments of the Moshers Island formation are a product of manganese oxide precipitation related to the development of anoxic water conditions (Waldron 1992), presumably in deep water. Although the Moshers Island formation is greatly elevated in manganese, some carbonate beds in the underlying Government Point and Green Harbour formations also contain elevated manganese concentrations (White and Barr, in press). In contrast, the Goldenville Group in the northwestern area lacks significant manganese concentrations. Whether the anoxic water conditions are related to water depth, sea-level changes, or stagnant oceanic circulation (c.f., Waldron 1992) these anoxic conditions periodically existed throughout the water column during deposition of the
Goldenville Group in the southern area but are not recorded in the sediments of the northwestern area.

The differences between the northwestern and southeastern areas suggest that they were originally farther apart, consistent with a considerable amount of shortening and strike slip motion along the Chebogue Point shear zone. Sparse paleocurrent data indicate that sediment sources may have been located to the south of the southeastern area and north of the northwestern area, consistent with a rift environment in which sediments were derived from both sides of the rift (Waldron et al. 2009).

\section{CONCLUSIONS}

The Goldenville and Halifax groups constitute a thick (>11 km) upper Proterozoic to Lower Ordovician clastic turbiditic succession probably deposited in a major rift setting along the Gondwanan margin. In southwestern Nova Scotia, they are divided into several formations and members that can be traced across the area but that show significant stratigraphic differences across the Chebogue Point shear zone. The Silurian White Rock Formation and Early Devonian Torbrook Formation, together with two suites of mafic sills, are confined to the northwestern area. Hence, the Chebogue Point shear zone marks a major tectonostratigraphic boundary within Meguma. Preliminary results from mapping in the Halifax area and eastern Meguma (Horne and Pelley 2007; White et al. 2008, 2009a) suggest that the formations defined in this study also extend into those areas. Although the newly defined formations meet many of the criteria necessary for acceptance as formal units, their extent and thickness make the rigorous measurement and description of type sections as specified by the North American Commission on Stratigraphic Nomenclature (2005) an impossible task at this point in time. However, the establishment of these formations satisfies the long-standing needs, as recognized by Schenk $(1995,1997)$ for modern, regionally consistent terminology in order to move forward in our understanding of the geological evolution of the Meguma terrane.

\section{ACKNOWLEDGEMENTS}

Support for the Southwest Nova Scotia Mapping Project was provided by the Nova Scotia Department of Natural Resources (NSDNR) operating budget for Chris White. Rick Horne and numerous students contributed to the mapping and data processing of the western and southern half of Meguma. I thank Sandra Barr, Nick Culshaw, Rick Horne, Becky Jamieson, Dan Kontak, Rob Raeside, Peter Reynolds, Bob Ryan, and John Waldron for stimulating discussions on the geology of Meguma. Tracy Lenfesty and Janelle Brenton are thanked for her help in the departmental library. An earlier version of the manuscript was reviewed by Trevor MacHattie and Sandra Barr 
who provided useful and encouraging comments. The through reviews of Leslie Fyffe, John Waldron, Robert Fensome, and Graham Williams led to substantial improvements in this paper. This paper is published with the permission of the Director, NSDNR.

\section{REFERENCES}

Ami, A.M. 1900. Synopsis of the geology of Canada. Preceedings and Transactions of the Royal Society of Canada, New Series, 6, pp. 194-195.

Bailey, L.W. 1896. Report on the geology of southwest Nova Scotia embracing the counties of Queens, Shelburne, Yarmouth, Digby and parts of Annapolis. Geological Survey of Canada Annual Report, New Series, 19, part M, pp. 1-154.

Barr, S.M., Doyle, E.M., and Trapasso, L.S. 1983. Geochemistry and tectonic implications of mafic sills in Lower Paleozoic formations of southwestern Nova Scotia. Maritime Sediments and Atlantic Geology, 19, pp. 73-87.

Bell, W.A. 1929. Horton-Windsor District, Nova Scotia. Geological Survey of Canada Memoir 155, $263 \mathrm{p}$.

Binney, W.P., Jenner, K.A., Sangster, A.L., and Zentilli, M. 1986. A stratabound zinc-lead deposit in Meguma Group metasediments at Eastville, Nova Scotia. Maritime Sediments and Atlantic Geology, 22, pp. 65-88.

Bouyx, E., Blaise, J., Brice, D., Degardin, J.M., Goujet, D., Gourvennec, R., Le Menn, J., Lardeux, H., Morzadec, P., and Paris, F. 1997. Biostratigraphie et paleobiogeographie du Siluro-Devonien de la zone de Meguma (NouvelleEcosse, Canada). Canadian Journal of Earth Sciences, 34, pp. 1295-1309. doi:10.1139/e17-103

Campbell, J. 1863. Report on Nova Scotia gold fields. Report to Joseph Howe, Provincial Secretary. Halifax, Nova Scotia, $12 \mathrm{p}$.

Clarke, D.B., MacDonald, M.A., and Tate, M.C. 1997. Late Devonian mafic-felsic magmatism in the Meguma Zone, Nova Scotia. In The nature of magmatism in the Appalachian orogen. Edited by A.K. Sinah, J.F. Whalen, and J.P. Hogan. Geological Society of America Memoir 191, pp.107-127.

Crosby, D.G. 1962. Wolfville map-area, Nova Scotia (21 H 1). Geological Survey of Canada Memoir 325, 67 p.

Culshaw, N., and Leisha, M. 1997. Alleghanian reactivation of the Acadian fold belt, Meguma Zone, southwest Nova Scotia. Canadian Journal of Earth Sciences, 34, pp. 833-847. doi:10.1139/e17-068

Culshaw, N., and Reynolds, P. 1997. ${ }^{40} \mathrm{Ar} /{ }^{39} \mathrm{Ar}$ age of shear zones in the southwest Meguma Zone between Yarmouth and Meteghan, Nova Scotia. Canadian Journal of Earth Sciences, 34, pp. 848-853. doi:10.1139/e17-069

Cumming, L.M. 1985. A Halifax slate graptolite locality, Nova Scotia. Geological Survey of Canada, Current Research, part A., Paper 85-1A, pp. 215-221.

Dostal, J., Keppie, D.J. Jutras, P., Miller, B.V., and Murphy, B.J. 2006. Evidence for the granulite-granite connection: penecontemporaneous high-grade metamorphism, granitic magmatism and core complex development in the Liscomb Complex, Nova Scotia, Canada. Lithos, 86, pp. 77-90. doi:10.1016/j.lithos.2005.04.002

Doyle, E.M. 1979. Geology of the Bear River area, Digby and Annapolic counties, Nova Scotia. Unpublished M.Sc thesis, Acadia University, Wolfville, Nova Scotia, 216 p.

Eberz, G.W., Clarke, D.B., Chatterjee, A.K., and Giles, P.S. 1991. Chemical and isotopic composition of the lower crust beneath the Meguma Lithotectonic Zone, Nova Scotia: evidence from granulite facies xenoliths. Contributions to Mineralogy and Petrology, 109, pp. 69-88. doi:10.1007/ BF00687201

Faribault, E.R. 1903. Deep gold mining. The Nova Scotian. Special Mining Number, pp. 22-28.

Faribault, E.R. 1908. Province of Nova Scotia, Halifax County, City of Halifax sheet, No. 68; Geological Survey Branch of Canada, Department of Mines, Publication No. 1019, scale 1:63 360 .

Faribault, E.R. 1914. Greenfield and Liverpool Town mapareas, Nova Scotia. Geological Survey of Canada Summary Report 1912, pp. 372-382.

Faribault, E.R., Armstrong, P., and Wilson, J.T. 1938a. Liverpool Sheet (East Half), Queens and Lunenburg Counties, Nova Scotia. Department of Mines and Resources, Mines and Geology Branch, Map 439A, scale 163,360.

Faribault, E.R., Armstrong, P., and Wilson, J.T. 1938b. Liverpool Sheet (West Half), Queens County, Nova Scotia. Department of Mines and Resources, Mines and Geology Branch, Map 440A, scale 163,360.

Gingras, M.K., Waldron, J.W.F., White, C.E., and Barr, S.M. in press. The evolutionary significance of a lower Cambrian trace fossil assemblage from the Meguma terrane, Nova Scotia. Canadian Journal of Earth Sciences.

Greenough, J.D., Krogh, T.E., Kamo, S.L., Owen, J.V., and Ruffman, A. 1999. Precise U-Pb dating of Meguma basement xenoliths: new evidence for Avalonian underthrusting. Canadian Journal of Earth Sciences, 36, pp. 15-22. doi:10.1139/cjes-36-1-15

Hall, L.R. 1981. Geology of the LaHave River area, Lunenburg County, Nova Scotia. Unpublsihed M.Sc. Thesis, Acadia University, Wolfville, Nova Scotia, 161 p.

Harris, I.M., and Schenk, P.E. 1975. The Meguma Group. Maritime Sediments, 11, pp. 25-46.

Hibbard, J.P., van Staal, C.R., Rankin, D., and Williams H. 2006. Lithotectonic map of the Appalachian orogen (north), Canada-United States of America. Geological Survey of Canada Map 02041A, 1 sheet, scale 1:1 500000.

Horne, R.J., and Pelley, D. 2007. Geological transect of the Meguma terrane from Centre Musquodoboit to Tangier. In Mineral Resources Branch, Report of activities 2006. Edited by D.R. MacDonald. Nova Scotia Department of Natural Resources, Report ME 2007-1, pp. 71-89.

Horne, R.J., White, C.E., Muir, C., Young, M.D., and King, M.S. 2000. Geology of the Weymouth-Church Point area 
(NTS 21A/05 and 21B/08), southwest Nova Scotia. In Report of Activities 1999. Edited by D.R. MacDonald, and K.A. Mills. Nova Scotia Department of Natural Resources, Mines and Energy Branch Report ME 2000-1, pp. 75-91.

Horne, R.J., Ryan, R.J., Corey, M.C., and Fox, DL. 2009a. Bedrock Geology Map of the Waverley Area, Part of NTS Sheet 11D/13 (Sheet 1 of 4), Halifax County, Nova Scotia. Nova Scotia Department of Natural Resources, Open File Map ME 2009-002, scale 1:25000.

Horne, R.J., Ryan, R.J., Corey, M.C., and Fox, DL. 2009b. Bedrock Geology Map of the Pockwock Lake Area, Part of NTS Sheet 11D/13 (Sheet 2 of 4), Halifax and Hants Counties, Nova Scotia. Nova Scotia Department of Natural Resources, Open File Map ME 2009-003, scale 1:25 000.

Horne, R.J., Ryan, R.J., Corey, M.C., and Fox, DL. 2009c. Bedrock Geology Map of the Uniacke Area, Part of NTS Sheet 11D/13 (Sheet 3 of 4), Halifax and Hants Counties, Nova Scotia. Nova Scotia Department of Natural Resources, Open File Map ME 2009-004, scale 1:25 000.

Horne, R.J., Ryan, R.J., Corey, M.C., and Fox, DL. 2009d. Bedrock Geology Map of the Grand Lake Area, Part of NTS Sheet 11D/13 (Sheet 4 of 4), Halifax and Hants Counties, Nova Scotia. Nova Scotia Department of Natural Resources, Open File Map ME 2009-004, scale 1:25 000.

Hwang, S.G. 1985. Geology and structure of the Yarmouth area, southwestern Nova Scotia. Unpublished M.Sc. thesis, Acadia University, Wolfville, Nova Scotia, 212 p.

James, J.A. 1998. Stratigraphy, petrochemistry, and economic potential of the Silurian New Canaan Formation, Meguma terrane. Unpublished B.Sc.H. thesis, Acadia University, Wolfville, Nova Scotia, 111 p.

Jensen, L.R. 1975. The Torbrook Formation. In Ancient Sediments of Nova Scotia. Edited by I.M. Harris. Society of Economic Paleontologists and Mineralogists, Eastern Section Guidebook, pp. 63-74.

Keen, C.E., Kay, W.A., Keppie, J.D., Marillier, F., Pe-Piper, G., and Waldron, J.W.F. 1991a. Deep seismic reflection data from the Bay of Fundy and Gulf of Maine: tectonic implications for the northern Appalachians.Canadian Journal of Earth Sciences, 28, pp. 1096-1111. doi:10.1139/e91-099

Keen, C.E., MacLean, B.C., and Kay, W.A. 1991b. A Deep Seismic Reflection Profile across the Nova Scotia Continental Margin, Offshore Eastern Canada. Canadian Journal of Earth Sciences, 28, pp. 1112-1120. doi:10.1139/e91-100

Keppie, J.D. (Compiler) 2000. Geological map of the province of Nova Scotia. Nova Scotia Department of Natural Resources and Energy, Map ME 2000-1, 1 sheet, scale 1500 000.

Keppie, J.D., and Krogh, T.E. 1999. U-Pb geochronology of Devonian granites in the Meguma terrane of Nova Scotia, Canada: Evidence for hotspot melting of a Neoproterozoic source. Journal of Geology, 107, pp. 555-568. doi:10.1086/314369

King E 1935. The G-H boundary at Fairview, ns. Proc. N Scotian inst sci, 19-1, pp. 114-118.
King, M.S. 2006. Airborne Magnetic Calculated Second Vertical Derivative Images for individual NTS sheets 21A/03, $21 \mathrm{~A} / 04,21 \mathrm{~A} / 07,21 \mathrm{~A} / 10,20 \mathrm{P} / 13,20 \mathrm{P} / 14$, and parts of $21 \mathrm{~A} / 01,21 \mathrm{~A} / 02,21 \mathrm{~A} / 05,21 \mathrm{~A} / 06,21 \mathrm{~A} / 08,21 \mathrm{~A} / 15,21 \mathrm{~B} / 01$, $21 \mathrm{~B} / 08,20 \mathrm{P} / 05,20 \mathrm{P} / 06,20 \mathrm{P} / 10,20 \mathrm{P} / 11,20 \mathrm{P} / 12,20 \mathrm{P} / 15$, $20 \mathrm{O} / 09$ and 20O/16, Western Meguma area of Nova Scotia (20 m by $20 \mathrm{~m}$ resolution). Nova Scotia Department of Natural Resources, Digital Product ME 372, Version 1. URL <http://www.gov.ns.ca/natr/meb/download/dp372. asp $>$ August 2009.

Lane, T.E. 1975. Stratigraphy of the White Rock Formation. Maritime Sediments, 11, pp. 87-106.

Lane, T.E. 1981. The stratigraphy and sedimentology of the White Rock Formation (Silurian), Nova Scotia, Canada. Unpublished M.Sc thesis, Dalhousie University, Halifax, Nova Scotia, $270 \mathrm{p}$.

Loncarevic, B.D., Barr, S.M., Raeside, R.P., Keen, C.E., and Marillier, F. 1989. Northeastern extension and crustal expression of terranes from Cape Breton Island, Nova Scotia, based on geophysical data. Canadian Journal of Earth Sciences, 26, pp. 2255-2267.

Mahoney, K.L. 1996. The contact metamorphic aureole of the South Mountain Batholith, Nova Scotia. Unpublished M.Sc. thesis, Acadia University, Wolfville, Nova Scotia, 153 p.

MacDonald, L.A., Barr, S.M., White, C.E., and Ketchum, J.W.F. 2002. Petrology, age, and tectonic setting of the White Rock Formation, Meguma Terrane, Nova Scotia; evidence for Silurian continental rifting. Canadian Journal of Earth Sciences, 39, pp. 259-277. doi:10.1139/e01-074

MacLean, N.J., Barr, S. M., White, C.E., and Ketchum, J.W.F. 2003. New U-Pb (zircon) age and geochemistry of the Wedgeport Pluton, Meguma terrane, Nova Scotia. Atlantic Geology, 39, pp. 239-253.

Moran, P.C., Barr, S.M., White, C.E., and Hamilton, M.A. 2007. Petrology, age, and tectonic setting of the Seal Island Pluton, offshore southwestern Nova Scotia. Canadian Journal of Earth Sciences, 44, pp. 1467-1478. doi:10.1139/E07$\underline{023}$

Moynihan, D. 2003. Structural geology, metamorphic petrology and ${ }^{40} \mathrm{Ar} /{ }^{39} \mathrm{Ar}$ geochronology of the Yarmouth area, southwest Nova Scotia. Unpublished M.Sc. thesis, Dalhousie University, Halifax, Nova Scotia, 234 p.

Murphy, J.B., Fernández-Suárez, J., Keppie, J.D., and Jeffries, T.E. 2004a. Contiguous rather than discrete Paleozoic histories for the Avalon and Meguma Terranes based on detrital zircon data. Geology, 32, pp. 585-588. doi:10.1130/ G20351.1

Murphy, J.B., Pisarevsky, S.A., Nance, R.D., and Keppie, J.D. 2004b. Neoproterozoic - Early Paleozoic evolution of periGondwanan terranes: implications for Laurentia-Gondwana connections. International Journal of Earth Sciences, 93, pp. 659-682. doi:10.1007/s00531-004-0412-9

Mutti, E. 1992. Turbidite sandstones, Parma Italy, AGIP and Instituto di Geologia, University of Parma, 275 p.

North American Commission on Stratigraphic Nomenclature 2005. North American Stratigraphic Code. American As- 
sociation of Petroleum Geologists Bulletin, 89, pp. 15471591.

O'Brien, B.H. 1985. Preliminary report on the geology of the LaHave River area, Nova Scotia. In Current Research, Part A, Geological Survey of Canada Paper 85-1A, pp. 785-794.

O'Brien, B.H. 1986. Preliminary report on the geology of the Mahone Bay area, Nova Scotia. In Current Research, Part A. Geological Survey of Canada Paper 86-1A, pp. 439-444. O’Brien, B.H. 1988. A Study of the Meguma Terrane in Lunenburg County, Nova Scotia. Geological Survey of Canada, Open File 1823, 139 p.

Owen, J.V., Greenough, J.D., Hy, C., and Ruffman, A. 1988. Pelitic xenoliths in a mafic dykes at Popes Harbour, Nova Scotia: Implications for the basement of the Meguma Group.Canadian Journal of earth Sciences, 25, pp. 14641471. doi:10.1139/e88-139

Palacios T., Jensen, S., Barr, S.M., White, C.E., and Miller, R.F. 2009. Preliminary results from an on-going study of acritarchs in Cambrian and Lower Ordovician rocks of Nova Scotia and New Brunswick. Atlantic Geology, 45, pp. 39-40.

Pratt, B.R., and Waldron, J.W.F. 1991. A Middle Cambrian trilobite faunule from the Meguma Group of Nova Scotia. Canadian Journal of Earth Sciences, 28, pp. 1843-1853.

Reynolds, P.H., Clarke, D.B., and Bogutyn, P.A. 2004. ${ }^{40} \mathrm{Ar} /{ }^{39} \mathrm{Ar}$ laser dating of zoned white micas from the Lake Lewis leucogranite, South Mountain batholith, Nova Scotia, Canada. The Canadian Mineralogist, 42, pp. 1129-1137. doi:10.2113/gscanmin.42.4.1129

Ruffman, A., and Greenough, J.D. 1990. The Weekend dykes, a newly recognized mafic dyke swarm on the eastern shore of Nova Scotia, Canada. Canadian Journal of Earth Sciences, 27, pp. 644-648. doi:10.1139/e90-061

Ryan, R.J., Fox, D., Horne, R.J., Corey, M.C., and Smith, P.K. 1996. Preliminary stratigraphy of the Meguma Group in central Nova Scotia. In Minerals and Energy Branch Report of Activities 1995. Edited by D.R. MacDonald. Nova Scotia Department of Natural Resources Report ME 1996001, pp. 27-34.

Sangster, A.L. 1990. Metallogeny of the Meguma Terrane, Nova Scotia. In Mineral deposit studies in Nova Scotia, Volume 1. Edited by A.L. Sangster. Geological Survey of Canada, Paper 90-8, pp. 115-162.

Schenk, P.E. 1970. Regional variations of the flysch-like Meguma Group (lower Paleozoic) of Nova Scotia compared to recent sedimentation off the Scotian Shelf. In Flysch sedimentology in North America. Edited by J. Lajoie. Geological Association of Canada Special Paper 7, pp. 127-153.

Schenk, P.E. 1971. Southern Atlantic Canada, northwestern Africa and continental drift. Canadian Journal of Earth Sciences, 8, pp. 1218-1251.

Schenk, P.E. 1975. A regional synthesis. In Ancient sediments of Nova Scotia. Edited by I.M. Harris. Eastern Section Society of Economic Paleontologists and Mineralogists, 1975 Field Trip Guidebook, pp. 9-16.

Schenk, P.E. 1981. The Meguma Zone of Nova Scotia - a remnant of Western Europe, South America, or Africa? In Geol- ogy of North Atlantic borderlands. Edited by J.M. Kerr, A.J., Ferguson, and L.C. Machan. Canadian Society of Petroleum Geologists Memoir 7, pp.119-148.

Schenk, P.E. 1991. Events and sea level changes on Gondwana's margin: the MegumaZone (Cambrian to Devonian) of Nova Scotia, Canada. Geological Society of America Bulletin, 103, pp. 512-521. doi:10.1130/0016-7606(1991)103<0512:EAS $\mathrm{LCO}>2.3 . \mathrm{CO} ; 2$

Schenk, P.E. 1995. Meguma Zone. In Geology of the Appalachian-Caledonian Orogen in Canada and Greenland. Edited by $\mathrm{H}$. Williams. Geological Survey of Canada, Geology of Canada, 6, pp. 261-277.

Schenk, P.E. 1997, Sequence stratigraphy and provenance on Gondwana's margin: the Meguma Zone (Cambrian to Devonian) of Nova Scotia, Canada. Geological Society of America Bulletin, 109, pp. 395-409. doi:10.1130/00167606(1997)109<0395:SSAPOG >2.3.CO;2

Stevenson, I.M. 1959. Shubenacadie and Kennetcook map areas, Colchester, Hants, and Halifax counties, Nova Scotia. Geological Survey of Canada Memoir 302, 88 p.

Stow, D.A.V., Alam, M., and Piper, D.J.W. 1984. Sedimentology of the Halifax Formation, Nova Scotia: Lower Paleozoic fine-grained turbitites. In Fine grained sediments: deep water processes and facies. Edited by D.J.W. Piper and D.A.V. Stow. Geological Society of London, Special Publication 15 , pp. 127-144.

Taylor, F.C. 1967. Reconnaissance Geology of Shelburne maparea, Queens, Shelburne, and Yarmouth Counties, Nova Scotia. Geological Survey of Canada Memoir 349, 83 p.

Taylor, F.C. 1969. Geology of the Annapolis-St. Marys Bay map-area, Nova Scotia. Geological Survey of Canada Memoir 358, 65 p.

van Staal, C. R., 2007. Pre-Carboniferous tectonic evolution and metallogeny of the Canadian Appalachians. In Mineral Resources of Canada: A synthesis of major deposit types, district metallogeny, the evolution of geological provinces, and exploration methods. Edited by W.D. Goodfellow. Geological Association of Canada, Mineral Deposits Division, Special Publication 5, pp. 793-818.

van Staal, C.R., Dewey, J.F., MacNiocaill, C., and McKerrow, W.S. 1998. The Cambrian-Silurian tectonic evolution of the northern Appalachian and British Caledonides: history of a complex, west and southwest Pacific-type segment of Iapetus. In Lyell: the Past is the Key to the Present. Edited by D.J. Blundell, and A.S. Scott. Geological Society, London, Special Publication 143, pp. 199-242.

Waldron, J.W.F. 1987. Sedimentology of the Goldenville-Halifax transition in the Tancook Island area, South Shore, Nova Scotia. Geological Survey of Canada, Open File 1535, 49 p.

Waldron, J.W.F. 1988. Determination of finite strain in bedding surfaces using sedimentary structures and trace fossils: a comparison of techniques. Journal of Structural Geology 10, pp. 273-281. doi:10.1016/0191-8141(88)90060-0

Waldron, J.W.F. 1992. The Goldenville-Halifax transition, Mahone Bay, Nova Scotia: relative sea-level change in the 
Meguma source terrane. Canadian Journal of Earth Sciences, 29, pp. 1091-1105.

Waldron, J.W.F., and Jensen, L.R. 1985. Sedimentology of the Goldenville Formation, eastern shore, Nov Scotia. Geological Survey of Canada Paper 85-15, 31 p.

Waldron, J.W.F., White, C.E., Barr, S.M., Simonetti, A., and Heaman, L.M., 2009. Provenance of the Meguma terrane, Nova Scotia: rifted margin of early Paleozoic Gondwana. Canadian Journal of Earth Sciences, 46, pp. 1-8. doi:10.1139/E09-004

White, C.E. 2003. Preliminary bedrock geology of the area between Chebogue Point, Yarmouth County, and Cape Sable Island, Shelburne County, southwestern Nova Scotia. In Minerals and Energy Branch, Report of Activities 2002. Edited by D.R. MacDonald. Nova Scotia Department of Natural Resources, Minerals and Energy Branch, Report 20031, pp. 127-145.

White, C.E. 2005. Geology of the area between Lockeport, Liverpool and Lake Rossignol, Shelburne and Queens counties, southwestern Nova Scotia. In Mineral Resources Branch, Report of Activities 2004. Edited by D.R. MacDonald. Nova Scotia Department of Natural Resources, Report ME 2005-1, pp.129-144.

White, C.E. 2006. Preliminary bedrock geology of the Liverpool and Lake Rossignol map sheets (NTS 21A/02 and 21A/03), southern Nova Scotia. In Mineral Resources Branch, Report of Activities 2005. Edited by D.R. MacDonald. Nova Scotia Department of Natural Resources, Report ME 2006-1, pp. 149-163.

White, C.E. 2007. Preliminary bedrock geology of the Kejimkujic Lake map area (NTS21A/06, southern Nova Scotia. In Mineral Resources Branch, Report of activities 2006. Edited by D.R. MacDonald. Nova Scotia Department of Natural Resources, Report ME 2007-1, pp. 159-169.

White, C.E. 2008a. Preliminary bedrock geology of the New Germany map sheet (NTS 21A/10), southern Nova Scotia. In Mineral Resources Branch, Report of Activities 2007. Edited by D.R. MacDonald. Nova Scotia Department of Natural Resources, Report ME 2008-1, pp. 113-124.

White, C.E. 2008b. Defining the stratigraphy of the Meguma Supergroup in southern Nova Scotia: where do we go from here? Atlantic Geology, 44, p. 58.

White, C.E. 2010. Compilation of geochemical and petrographic data from the western and southern parts of the Goldenville and Halifax groups, Nova Scotia. Nova Scotia Department of Natural Resources, Open File Report 2010$001,18 \mathrm{p}$.

White, C.E. in press. Pre-Carboniferous bedrock geology of the Annapolis Valley area (NTS 21A/14, 15, and 16;21H/01 and 02), southern Nova Scotia. In Mineral Resources Branch, Report of Activities 2009. Edited by D.R. MacDonald. Nova Scotia Department of Natural Resources, Report ME 20101.

White, C.E., and Barr, S.M. 2004. Age and petrochemistry of mafic sills on the northwestern margin of the Meguma terrane in the Bear River - Yarmouth area of southwestern
Nova Scotia. In Mineral Resources Branch, Report of Activities 2003. Edited by D.R. MacDonald. Nova Scotia Department of Natural Resources, Report 2004-1, pp. 97-117. White, C.E., and Barr, S.M. in press. Petrochemistry of the Lower Paleozoic Goldenville and Halifax groups, southwestern Nova Scotia, Canada: implications for stratigraphy, provenance, and tectonic setting of Meguma. In From Rodinia to Pangea: The Lithotectonic Record of the Appalachian Region. Geological Society of America Memoir. White, C. E., and King, M. S. 2002. Preliminary Bedrock Geology of the Tusket Map Area (NTS 20P/13), southwestern Nova Scotia. In Minerals and Energy Branch, Report of Activities 2001. Edited by D.R. MacDonald. Nova Scotia Department of Natural Resources, Minerals and Energy Branch, Report ME 2002-1, pp. 141-158.

White, C.E., Horne, R.J., Muir, C., and Hunter, J. 1999. Preliminary bedrock geology of the Digby map sheet (21A/12), southwestern Nova Scotia. In Minerals and Energy Branch, Report of Activities 1998. Edited by D.R. MacDonald, and K.A. Mills. Nova Scotia Department of Natural Resources, Report ME 1999-1, pp. 119-134.

White, C.E., Horne, R.J., Teniere, P.J. Jodrey, M.J., and King, M.S. 2001. Geology of the Meteghan River-Yarmouth area: a progress report on the Southwest Nova Scotia Mapping Project. In Minerals and Energy Branch, Report of Activities 2000. Edited by D.R. MacDonald. Nova Scotia Department of Natural Resources, Report ME 2001, pp. 95-111.

White, C.E., Gingras, M.K., and Waldron, J.W.F. 2005a. New fossil evidence for an Early Cambrian age for the lower Goldenville Formation (Meguma Group), southwestern Nova Scotia. Atlantic Geology, 41, p. 83.

White, C.E., Gingras, M.K., and Waldron, J.W.F. 2005b. Significance of the High Head Member, southwestern Nova Scotia: new fossil evidence for a Late Neoproterozoic(?) to Early Cambrian age for the lower Goldenville Formation. Nova Scotia Department of Natural Resources, Mineral Resources Branch, Open File Illustration ME 2005-1, 1 sheet.

White, C.E., Barr, S.M., and Toole, R.M. 2006. Stratigraphy, tectonic setting and provenance of the Meguma Group, southwestern Nova Scotia. Nova Scotia Department of Natural Resources, Minerals and Energy Branch, Open File Illustration ME 2006-2, 1 sheet.

White, C.E., Barr, S.M., Horne, R.J., and Hamilton, M.A. 2007. The Neoacadian orogeny in the Meguma terrane, Nova Scotia, Canada. In 42st Annual Meeting Geological Society of America, Northeastern Section, March 12-14, 2007, Abstracts with Programs 2007, 39, p. 69.

White, C.E., Bell, J.A., McLeish, D.F., MacDonald, M.A., Goodwin, T.A., and MacNeil, J.D. 2008. Geology of the Halifax Regional Municipality, central Nova Scotia. In Mineral Resources Branch, Report of Activities 2007. Edited by D.R. MacDonald. Nova Scotia Department of Natural Resources, Report ME 2008-1, pp. 125-139.

White, C.E., Scallion, K., and MacHattie, T. 2009a. Geology of the Governor Lake area ('Liscomb Complex'), parts of NTS sheets 21E/01, 02, 07, and 08, central Nova Scotia. In 
Mineral Resources Branch, Report of Activities 2008. Edited by D.R. MacDonald. Nova Scotia Department of Natural Resources, Report ME 2009-1, pp. 151-165.

White, C.E. Scallion, K, Barr, S.M., and Jamieson, R.A. 2009 b. The Liscomb Complex, Meguma terrane, Nova Scotia: basement or urban legend? Atlantic Geology, 45, pp. 48-49.

Williams, G.L., Fyffe, L.R., Wardle, R.J., Colman-Sadd, S.P., and Boehner, R.C. 1985. Lexicon of Canadian Stratigraphy, Volume VI Atlantic Region. Canadian Society of Petroleum Geologists, Calgary, $572 \mathrm{p}$.

Williams, H. 1979. Appalachian Orogen in Canada. Canadian Journal of Earth Sciences, 16, pp. 792-807. doi:10.1139/ e79-070

Williams, H., and Hatcher, R.D. 1982. Suspect terranes and accretionary history of the Appalachian orogen. Geology, 10, pp. 530-536. doi:10.1130/0091-7613(1982)10<530:ST $\underline{\mathrm{AAHO}}>2.0 . \mathrm{CO} ; 2$
Woodman, J.E. 1902. Geology of the Moose River district, Halifax County, Nova Scotia; together with the pre-Carboniferous history of the Meguma series. Unpublished Ph.D. thesis, Harvard University, Cambridge, Massachusetts, $353 \mathrm{p}$.

Woodman, J.E. 1904a. Nomenclature of the gold-bearing metamorphic series of Nova Scotia. American Geologist, 33, pp. 363-370.

Woodman, J.E. 1904b. The sediments of the Meguma Series of Nova Scotia. American Geologist, 34, pp. 13-34.

Zentilli, M., Graves, M.C., Mulja, T., and MacInnis, I. 1986. Geochemical characterization of the Goldenville - Halifax transition of the Meguma Group of Nova Scotia: preliminary report. Geological Survey of Canada Paper 86-1A, pp. 423-428. 